\title{
Between Hierarchy and Individuality: the Andean Community of Nations' historical rationalities
}

\author{
Pablo Garcés* ${ }_{\mathbb{B}}$
}

\begin{abstract}
In its 50 years, CAN has faced important challenges, some have even threatened its existence. Nevertheless, the fact that it has survived is a testament to its success. On the face of greatly changing political and economic environments, the continuity of its work can be explained by its ability to adapt to the situation. In this half of century, the mechanism has undergone more than one existential crisis and it has tackled each with important self-reforms. These modifications have sought to renew its relevancy. In order to make sense of this adaptation, this article uses grid-group cultural theory to identify the main rationalities or worldviews that have driven this regional integration process. The analysis shows that CAN has mainly moved between hierarchical and individualistic ways of life, and points to some implications for its near future.
\end{abstract}

Key words: regional integration; Latin American integration; Andean Pact; Andean community; grid-group cultural theory; multiple rationalities; wicked problems

\section{Entre jerarquía e individualidad: las racionalidades históricas de la Comunidad Andina de Naciones}

\section{Resumen}

En sus 50 años de vida, la CAN ha enfrentado importantes desafíos, algunos de los cuales incluso han amenazado su existencia. Sin embargo, el hecho de que haya sobrevivido es un testimonio de su éxito. Frente a entornos políticos y económicos muy cambiantes, la continuidad de su trabajo se explica por su capacidad de adaptación a las circunstancias. En este medio centenar de años, el organismo ha atravesado más de una crisis existencial y las ha abordado con importantes autorreformas. Estas modificaciones han buscado renovar su relevancia. Con el fin de darle sentido a esta adaptación, este artículo utiliza la teoría cultural de cuadrícula y grupo (grid-group cultural theory) para identificar las principales racionalidades o visiones del mundo que han impulsado este proceso de integración regional. El análisis muestra que CAN se ha movido principalmente entre formas de vida jerárquicas e individualistas y señala algunas implicaciones para su futuro cercano.

Palabras clave: integración regional; integración latinoamericana; Pacto Andino; Comunidad Andina; grid-group cultural theory; múltiples racionalidades; problemas inquietantes

* Docente investigador del Instituto de Altos Estudios Nacionales, Ecuador. pablo.garces@iaen.edu.ec>. Recibido: 28 de junio de 2020 | Revisado: 14 de julio de 2020 | Aceptado: 23 de septiembre de 2020. Para citar este artículo: Garcés Velástegui, Pablo. "Between Hierarchy and Individuality: the Andean Community of Nations' historical rationalities". Comentario Internacional 20 (2020):55-77. doi: 10.32719/26312549.2020.20.1.4 


\section{Introduction}

T

raditionally regional integration mechanisms have been regarded as means to attaint some end. Historically, the ends pursued by Latin American integration mechanisms have oscillated between political autonomy and economic development. ${ }^{1}$ CAN has not been the exception to this rule. It was originally created to harness the potential of neighboring countries in order to address some problem, inter alia: enlarge their markets, generate economies of scale, improve competitiveness, become attractive to other relatively wealthier countries and increase their bargaining power vis-à-vis them.

In the pursuit of these goals, CAN has a mixed record. This situation has questioned the usefulness of the mechanism more than once. Not only that, but the very inner working of CAN has proven to be problematic, prompting member states to rethink its breadth and depth and reconsider its structure. In this sense, CAN not only has been a means to address a problem, usually the problem of development, ${ }^{2}$ but it seems to have been a problem itself. Despite its shortcomings, CAN has proven to be resilient, successfully adapting to changing environments, which have been described by the literature as inter alia new regionalism, ${ }^{3}$ post-hegemonic regionalism, ${ }^{4}$ strategic regionalism ${ }^{5}$ and postliberal regionalism. ${ }^{6}$ In this sense, it has not been problematic enough to disappear. Arguably, this can

1. José Briceño Ruiz, "Autonomía y desarrollo en el pensamiento integracionista latinoamericano" in Integración Latinoamericana y Caribeña: Política y Economía, ed. José Briceño, Andrés Rivarola, and Ángel Casas (Madrid: Fondo de Cultura Económica, 2012).

2. José Briceño Ruiz y Raquel Álvarez, "Modelos de Desarrollo y estrategias de integración en América Latina: una revisión crítica", Cuadernos sobre Relaciones Internacionales, Regionalismo y Desarrollo 1, n. ${ }^{\circ}$ 1 (2006): 63-87.

3. Philippe De Lombaerde, "El Nuevo Regionalismo en América Latina", UNU-CRIS Ocasional Papers O-2005/3, (2005): 1-24.

4. Pía Riggirozzi, "Re-territorializando consensos: Hacia un regionalismo post-hegemónico en América Latina", en América Latina y el Caribe: Nuevos actores, nuevos temas, nuevos desafíos, ed. Andrés Serbin, Laneydi Martínez, Haroldo Ramanzini (Buenos Aires: Coordinadora Regional de Investigaciones Económicas y Sociales, 2012), 129-51.

5. José Briceño Ruiz, "Regionalismo estratégico e interregionalismo en las relaciones externas del MERCOSUR", Revista Aportes para la Integración Latinoamericana 12, n. ${ }^{\circ} 15$ (2006): 30-45.

6. Antonio Sanahuja, "Regionalismo Postliberal y Multilateralismo en Sudamérica: el caso de UNASUR", en América Latina y el Caribe: Nuevos actores, nuevos temas, nuevos desafíos, ed. Andrés Serbin, Laneydi Martínez, Haroldo Ramanzini (Buenos Aires: Coordinadora Regional de Investigaciones Económicas y Sociales, 2012), 19-72. 
be explained by its ability to adapt to the challenges faced, which other mechanisms such as UNASUR, seem to lack.

Against this backdrop, it seems warranted to scrutinize that adaptation in order to make sense out of it. The relevant literature has suggested that regional integration is not just any problem but a wicked one. ${ }^{7}$ These are social problems that are loosely defined and, since they are regarded from different perspectives, can have multiple solutions. ${ }^{8}$ Such approach seems advised as it highlights the political nature of a regional integration initiative, always subject to the agenda of member states' governments. However, it poses a significant challenge: the multiple interpretations that can be given to this problem and, concomitantly, the multiple solutions.

To address that issue, it is necessary to have a framework that can respect that plurality while making its complexity workable. This article advances grid-group cultural theory. This approach provides a mutually exclusive and jointly exhaustive typology of four possible rationalities or worldviews into which such adaptation can fall. Shedding light on the issues thusly can prove useful to better understand the mechanism, its member states and their joint future.

In order to elaborate that argument, this article has a three-section structure, besides the introduction. The first section presents the theory and elaborates on its application to Latin American Integration. The second section looks at CAN historically through the lenses of the theory. Thus, the argument pays attention to CAN's inner working as well as the positions held by member states. The final section concludes.

\section{Grid Group Cultural Theory}

Grid-group cultural theory (henceforth GG), originally formulated within the field of anthropology, advances a functionalist alternative to the scrutiny of socio-cultural viability. ${ }^{9}$ It proposes an approach to the study

7. Pablo Garcés, "Latin American integration as a wicked problem: the case for a plural approach", Revista de Relaciones Internacionales, Estrategia y Seguridad 13, n. ${ }^{\circ} 1$ (2018): 93-117.

8. Horst Rittel and Melvin Weber, "Dilemmas in a general theory of planning", Policy Sciences 4, n. 2 (1973): 155-69.

9. Michael Thompson, Richard Ellis, and Aaron Wildavsky, Cultural Theory (Oxford: Westview Press, 1990). 
of society and social relations that highlights the social construction of the perceptions from which the world becomes intelligible. These vantage points are the worldviews or rationalities that influence interpretations of reality, the construction of its meanings and that which allows us to make sense out of it. ${ }^{10}$

GG suggests that the viability of different ways of life depends on the interaction between cultural bias and social arrangement, a relationship that can be mutually reinforcing. ${ }^{11}$ Regarding cultural bias, it is the category the denotes systems of beliefs and shared values. Apropos of social arrangements, they refer to the different formations of interpersonal relations which can make up distinct ways of life. Hence, members of a way of life perpetuate it by being and doing that which is established in the respective shared values and beliefs, which, in turn, contribute to the legitimization of those social arrangements.

Thus, this theory focuses on freedom of choice and its social constraints. Two dimensions lie at the center of the analysis: grid and group. These continua can encompass all the variation in the individual-society relations, human organization ${ }^{12}$ or sociality, ${ }^{13}$ providing thereby a useful heuristic device. Grid seeks to capture external perceptions and their influence on individual choice. It denotes the extent to which individual decisions are restricted by subjectivities or interpretations from outside of those making them. The more exacting the outward prescriptions the less space there is for individual autonomy. ${ }^{14}$ Group conveys the notion of collective membership or affiliation. This dimension captures the extent to which individuals are a part of bounded units. In this sense, the greater the individual's membership within a group, the less autonomy the individual enjoys. ${ }^{15}$

GG cultural theory combines the aforementioned dimensions to form an axis of coordinates. The result is four quadrants, each denoting a distinct

10. Wendy Bell, An Anthropological View of How Organizations Think (Melbourne: Monash University Faculty of Business \& Economics, 1997).

11. Thompson and Ellis, Wildavsky, Cultural Theory.

12. Christopher Hood, The Art of the State: Culture, Rhetoric and Public Management (Oxford: Oxford University Press, 1998).

13. Thompson, Ellis and Wildavsky, Cultural Theory.

14. Charles Lockhart, "The Social Construction of Cooperation: Egalitarian, Hierarchical, and Individualistic Faces of Altruism", in Culture and Social Theory / Aaron Wildavsky, ed. S-K. Chai and Brendon Swedlow (London: Transaction Publishers, 1998).

15. Ibíd. 
Figure 1

\section{GG cultural theory's four ways of life}

High Group

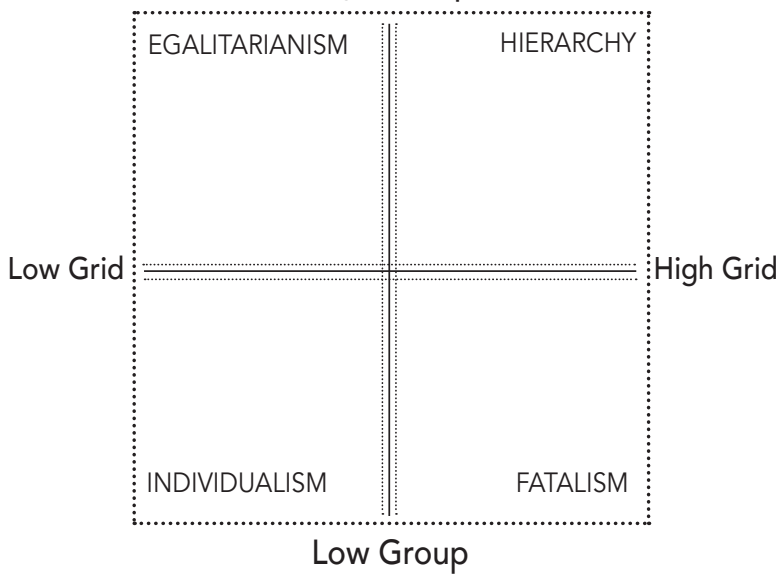

Douglas in Bell, An Anthropological View of How Organizations Thin.

way of life or worldview. These are four irreducible rationalities, mutually exclusive and jointly exhaustive, namely: hierarchy, fatalism, egalitarianism and individualism ${ }^{16}$ (see Figure 1). In order to elaborate on each, the following discussion introduces their basic assumptions for human agency and organizations before, following Garcés' argument, ${ }^{17}$ fleshing out the implications for regional integration, on the basis of what cooperation and conflict mean for each.

\section{Hierarchy}

At high grid and high group is hierarchy. Individuals with this worldview have their freedom of choice constraint in both dimensions. As such, it entails a relatively deeper as well as broader influence by external prescriptions and a greater influence by group members. Regarding group,

16. A fifth way of life is that or the hermit. This entails renouncing to any form of social life. Since this paper deals with regional integration, which is by its very nature an agreed upon collective undertaking, this way of life is irrelevant.

17. Pablo Garcés, "Latin America at the crossroads: cultural theory to address the wicked problem of regional integration with clumsy solutions", Revista de Relaciones Internacionales, Estrategia y Seguridad 14, n. $2(2019)$. 
their affiliations to collectivities determine their decisions. Apropos of grid, self-imposed prescriptions from without regulate their space of choice, which can be seen in the specialization of roles.

From this perspective human nature is flawed by nature and human beings are not trustworthy. They are, nonetheless, redeemable if governed by the right institutions in order to create certainty. ${ }^{18}$ Therefore, rules and laws are required in order to reduce uncertainty and increase the probability of optimal choices. Perhaps the best illustration of these institutions is the generation of roles to which individuals ought to comply, restricting thereby the scope of their agency. These roles are established by those in power, placed in the higher ranks.

As its label suggests, hierarchies are specifically created within this worldview. Therefore, organizations are considered ladders of authority". ${ }^{19}$ The controls put in place serve the purpose of keeping the lower ranks in place and maintaining the status quo. Thus, from this perspective, things and people out of place are problematic. In case such conflict occurs, the system turns to oversight in order to exercise control. ${ }^{20}$ Specifically, the system also has tools at its disposal to guarantee its survival, such as "upgrading, shifting sideways, downgrading, redefining". ${ }^{21}$

Regional integration, therefore, becomes an opportunity to place things in their right place within an anarchical international system. That is, it is an opportunity to bring order to the latter. It is an occasion to stablish rules with roles and responsibilities to members. By so doing, relatively more powerful members can consolidate their power with the generation of a hierarchy, whether formal or informal.

From this perspective the system comes first. Thus, while cooperation is alignment with the authority, placing things where they should be, conflict is when things are out of place. Actions that perpetuate the status quo are regarded as cooperative. Actions that threaten it are conflictive.

18. Michael Thompson, "Cultural Theory, Climate Change and Clumsiness", Economic and Political Weekly 38, n. $^{\circ} 48$ (2003): 5107-12.

19. Hood, The Art of the State: Culture, Rhetoric and Public Management.

20. Ibíd.

21. Mary Douglas, In the Acting Voice (Boston: Routledge \& Kegan Paul, 1982), 206. 


\section{Individualist}

At the antipodes of the previous world view, where low grid and low group collide, there is the individualist rationality. This system offers the most freedom of choice for the individual as there is neither group membership nor prescriptions imposed from without. Therefore, if there are constraints at any given time, they are considered as only conjunctural and subject to negotiation. ${ }^{22}$

True to its name, from this perspective, individuals are all there is. Moreover, they are atomistic and self-seeking by nature. ${ }^{23}$ The system is characterized by anarchy as there is a lack of authority. This, in turn, enables the establishment of self-authority. In the absence of a common authority, the freedom from control by others leads to the enablement to control others. Success in this system, thus, is measured in terms of the following acquired or the magnitude of control exercised. ${ }^{24}$

In this context, organizations are an arena. ${ }^{25}$ Individuals are concerned with relative gains and try to one up each other in order to get an advantage. Hence, competition is the strategy for control. ${ }^{26}$ Further, market becomes the mechanism to harness that competition into optimal outcomes. They are the only arrangements believed to reach equilibria when all participants are self-interested utility maximizers. ${ }^{27}$

Within this system, regional integration becomes unnecessary at best and a constraint at worst. The anarchy characterizing the system is what enables freedom and competition. Integration is an effort to limit both and, thus, detrimental to individualists seeking to gain whatever they can on the basis of what they regard as their merit. Rules and roles challenge this system and reduce the possibility of reward.

This worldview prioritizes the individual. Therefore, should regional integration initiatives take place, they are regarded as temporary instruments to further one's own agenda, which at the most basic is survival.

22. Michael Thompson and Richard Ellis, "Introduction: Political Cultures", in Culture and Social Theory / Aaron Wildavsky ed. Chai, Sun-Ki and Brendon Swedlow (London: Transaction Publishers, 1998).

23. Thompson, "Cultural Theory, Climate Change and Clumsiness".

24. Douglas, In the Acting Voice.

25. Hood, The Art of the State: Culture, Rhetoric and Public Management.

26. Ibíd.

27. Thompson, "Cultural Theory, Climate Change and Clumsiness". 
Conflict is constant in this as it is intrinsic to competition. Cooperation, in turn, is only possible to the extent it allows individuals to attain their self-interested goals.

\section{Egalitarian}

At the intersection of low grip and high group is located the egalitarian way of life. Concerning grid, there is a lack of externally imposed prescriptions on individual freedom of choice so there is are not predetermined specific roles. However, the influence exerted by the collective is rather great limiting personal freedom.

Within this rationality, individuals are regarded as equals and inherently solidary. Human nature is associated with caring and sharing, perverted only by inegalitarian institutions. ${ }^{28}$ Thus, egalitarian generate their identity in opposition to the other, which in this case are mainly those posing an antagonistic threat to them, namely hierarchies and markets. Human relationships turn ambiguous inside the collective due to the lack of specific roles distinguishing individuals ${ }^{29}$ which produces an increase in uncertainty relative to the other ways of life.

Equality also means anarchy, which makes consensus the decision-making mechanism. Therefore, conflict resolution becomes exacting. In case of conflict, the strategy is the exclusion of members. ${ }^{30}$ Because of the absence of authority to control and coerce, mutually is the mechanism to assess observance of commitments. ${ }^{31}$ Organizations, from this rationality, are regarded as collegial. ${ }^{32}$

Regional integration, according to this rationality, is an opportunity to infuse more equality into an international system dominated by other ways of life. However, regional integration takes the form of consensual decision making, rejecting attempts to impose rules over member states. In this sense, integration allows members to consolidate their worldview and identity, by opposing the alternatives.

28. Thompson, "Cultural Theory, Climate Change and Clumsiness".

29. Douglas, In the Acting Voice.

30. Thompson and Ellis, "Introduction: Political Cultures".

31. Hood, The Art of the State.

32. Ibíd. 
For egalitarians, cooperation is about solidarity and conflict about inequality. As such, member states cooperate to the extent they regard each other as equals, respecting agreements to each other and enforcing common rules, in the absence of authority. Conflict emerges from within and arises whenever there is a member that seeking power, threatening thereby the system's equality.

\section{Fatalist}

Finally, the last way of life is found at high grid and low group. In this system collective affiliation does not exert any influence on individual choice. However, there is substantial pressure from external prescriptions. Therefore, personal freedom is restricted by the differentiation of roles established by the social arrangement. ${ }^{33}$ These roles are produced by the higher ranks, wielding the power to make institutions. Thus, there is a hierarchy, at the bottom of which are fatalists, who are rule-takers, not rule-makers.

Human beings are self-interested but ultimately ineffective and human nature is seen as untrustworthy and fickle. ${ }^{34}$ The control mechanism within this worldview is contrived randomness. ${ }^{35}$ For fatalists, the world is uncertain, and agency is futile because their freedom of choice is externally constraint, against their will. As such, reality is unpredictable, and agency is meaningless. Hence, there is no mechanism of control within this worldview. Moreover, for this rationality organizations are gaming machines. ${ }^{36}$

Hence, cooperation and conflict are virtually absent as well. Cooperation and conflict are the product of agency and this is something lacking within this system. Since fatalists' agency is almost non-existent, because any effort is futile, unlikely to pay off and even detrimental to them, they have no incentives to change the status quo. Hence, fatalists do not have integration mechanisms reflecting their way of life, but fatalists are to be found within mechanisms being dominated by other worldviews.

33. Douglas, In the Acting Voice.

34. Thompson, "Cultural Theory, Climate Change and Clumsiness".

35. Hood, The Art of the State: Culture, Rhetoric and Public Management.

36. Ibíd. 
Figure 2

Human nature according to Grid/group cultural theory's four rationalities

High Group

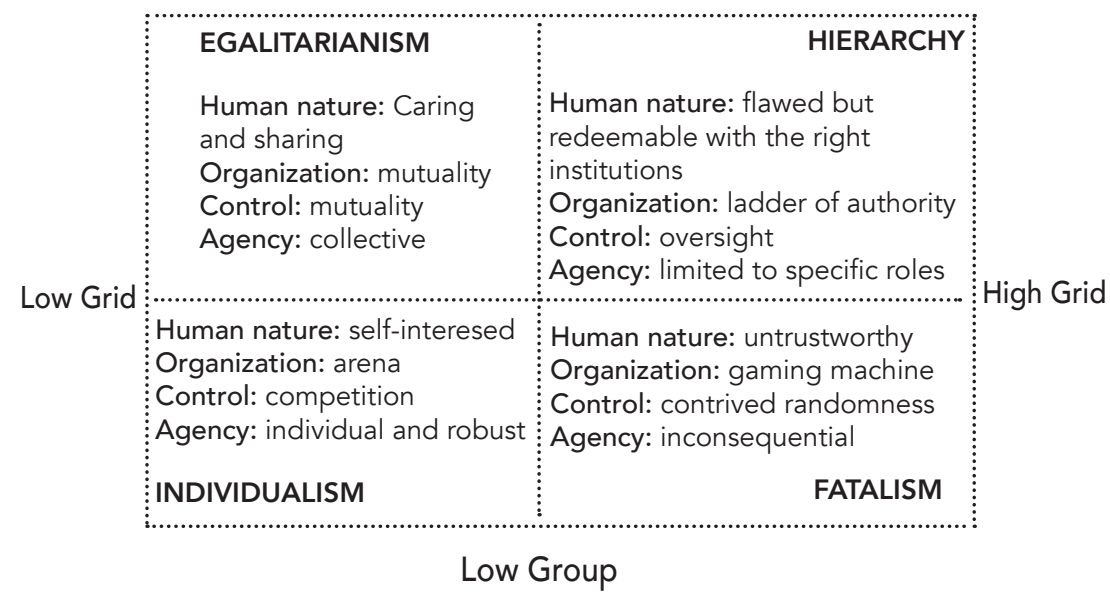

Source: Garcés, "Latin America at the crossroads".

These four worldviews or ways of life are also considered rationalities, which are interdependent. This interdependence accounts for change. Because these worldviews are determined by their members, i.e. the individuals that adhere to them, they are constantly competing for new members from other rationalities. Thus, change entails a zero-sum game. Because there is a limited number of individuals, one rationality's gain is another one's loss. Therefore, the viability of a worldview is given by its membership.

Moreover, change in the extent of ways of life is explained by surprise. The ever changing reality of the world incites new interpretations of phenomena. The latter prompt different values and beliefs leading to different actions and behaviors. As such, whenever there is a mismatch between the expectations generated within a rationality and the reality of world, there is surprise. Whether it is positive or negative, if expectations are not met by phenomena, there is surprise, and this is problematic. This is so, even in the case of positive surprise, because what is valuable from the perspective of a given rationality is its ability adequately account for the world, a bases on which people can confidently do and be, and, thus, provide some notion of certainty. It is understandable, therefore, that the definition of surprise matches that of a problem. 
Figure 3

Integration, conflict and cooperation from four rationalities or worldviews

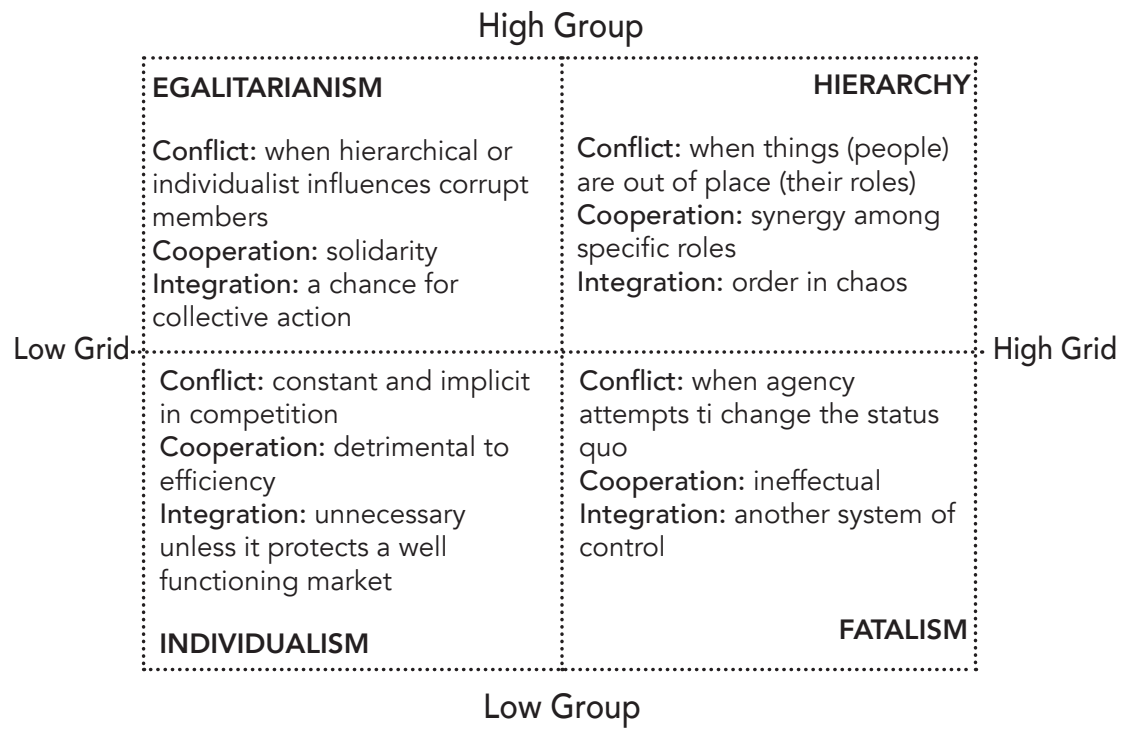

Source: Garcés, "Latin America at the crossroads".

How does surprise lead to change? Once sufficient surprise ensues, individuals are likely to reconsider their worldview, as it does not seem to adequately account for reality and move to another regarded more consistent with it. ${ }^{37}$ Therefore, the perceived inability of current beliefs to lead to adequate action given certain events motivates the change in beliefs.

\section{The Andean Community's rationalities}

The Andean Community (CAN) celebrated its 50th anniversary of creation last year. During this first half of century, the CAN has gone through important transitions taking place in the region and has proven to be a survivor despite the many challenges raised against it. Against this backdrop, it is warranted to assess this survival. The intuition behind this

37. Ibíd. 
project is that CAN's ability to move among the different worldviews has allow it to undergo many relevant changes. In this sense, this section discusses CAN historically, distinguishing different epochs according to the dominant rationality shown by the mechanism.

First Individualist Integration: 1969 - late 1980s

The Andean Pact (AP) was constituted by the Cartagena Agreement, which was signed by Bolivia, Colombia, Chile, Ecuador and Peru. A fifth member joined the group in 1973, Venezuela. The aim of member states was to generate a mechanism that would allow them to better reap the benefits of international trade. Relatively small countries, all of them, they were neither attractive for international investors nor able to individually negotiate and compete within large markets such as the US and Europe.

In this sense, pursuing their own self-interest, seeking to enhance their competitiveness in the international free market, member states decided to create a customs union. This initiative entails the establishment of a free trade zone for member states and a sole and unified tariff for third party states. The expectation behind supporting free trade was that the free movement of goods and services across borders would facilitate the access to neighboring markets and, with the incentive of competition, would allow production to be more competitive. The beneficiaries are consumers because of the increase in productivity and producers because of the opportunity to generate economies of scale. The aspiration behind the common tariff was the ability to increase the bargaining power of the group with third party states, so as to negotiate terms that they could not individually.

Carrying out these ambitious intentions, however, proved rather difficult and changes had to be made to the original program. In 1976, the Lima Protocol was signed in order to provide a more flexible schedule and rules for the elimination of tariffs and the establishment of the free trade zone. Although detrimental for the deadlines proposed by the mechanism, it was in the interest of the parties to implement a new program. This move shows the primacy of individual member states over the system.

The integration process suffers an important blow in 1976 with Chile's exit. Because of the economic and political situation in that country at that time, it considered it was better off alone and opted out of the mecha- 
nism. With a true individualist worldview, Chile assessed that its interests were better pursued individually and, as such, being part of AP was only a temporary undertaking.

The 1980 crisis represented another blow for the integration process. Member states prioritized internal affairs and succumbed to pressures to implement protectionist measures, despite the fact that these would threaten the integration. In particular, this situation affected the possibility to establish a customs union. Acting on their self-interest, member states turned to protectionism and pushed for changes within the mechanism. The result of this scenario is 1987's Quito Protocol, which established additional flexibility to the objectives and commitments originally decided on the Cartagena Agreement.

Member states of AP had to tackle a challenging scenario. The economic situation curtailed any prospect of growth and development in the short term. This had important consequences for the advancement of AP, not only de jure as highlighted above, but de facto as well. Trade among members was considerably affected and the expected benefits of the initiative became questionable.

\section{Moving to a hierarchical integration: late 1980s - early 2000s}

From the end of the 1980s and the beginning of the 1990s, AP underwent important changes seeking its institutionalization. This signals the starts of what has come to be labeled as new regionalism. ${ }^{38}$ In particular, these efforts aimed at securing the free trade zone and the customs union. In this sense, the Galapagos Summit (1989) established a strategic design guiding the efforts of member states. The Machu Picchu Meeting (1990) went a step farther creating an important organism, namely, the Andean Presidential Council. The Caracas Meeting (1991) recovered the focus on trade with the ratification of the agreements supporting the external common tariff and the harmonization of the exchange and monetary policies.

38. José Antonio Sanahuja, "Del regionalismo abierto al regionalismo post-liberal: crisis y cambio en la integración latinoamericana", in Anuario de la integración regional de América Latina y El Caribe, ed. Laneydi Martínez, Lázaro Peña and Mariana Vázquez (Buenos Aires: Coordinadora Regional de Investigaciones Económicas y Sociales, 2008). 
Finally, the Cartagena de Indias Meeting (1991) led to significant advancements in AP's policies, particularly in terms of its relationship with MERCOSUR. By 1993, the external common tariff was approved (Decision $335)$ by the Cartagena Agreement's Commission.

Hence, the AP sought to generate tangible results almost thirty years after its conception and they were produced rather close to one another. By 1991, the free trade zone was reactivated, ${ }^{39}$ which gained working condition for all member states by 1993. The incipient customs union, in turn, with the common external tariff for states outside the mechanism started in 1995.

This period, known also as open regionalism, was characterized by a combination of neoliberal as well as neo-structural ideas. ${ }^{40}$ The former emphasized inter alia minimal government, open markets, free trade, under the influence of the Washington Consensus. The latter, in turn, following historical ideas and concerns manifested by the United Nations Economic Commission for Latin America and the Caribbean (ECLAC) focused on employment, poverty and inequality.

The next step towards generating a structure and a working regime within AP is taken at the end of the 1990s. The Trujillo Protocol (1996) and the Sucre Protocol (1997) expand the original scope of action established by the Cartagena Agreement. In this sense, the mechanism moves from an exclusive focus on trade and technical matters to the addition of other dimensions, the most important of which are the political ones.

Not only is there a hierarchy for decision making among member states but also one for the inner workings of the mechanism itself. Beyond the inclusion of the Andean Presidential Council and the Andean Council of Foreign Ministers, perhaps the best illustrations of this move is the creation of the General Secretariat of the mechanism, with clear political attributions, which signals also the start of the Andean System of Integration (SAI by its acronym in Spanish). This move is so significant that it warrants a renaming of the integration initiative in 1996, from the Andean Pact to the Andean Community (CAN).

At the start of the new millennium, CAN put ambitious goals for itself. The Lima Presidential Summit (2000) established the commitment

39. Ibíd.

40. Briceño Ruiz, "Autonomía y desarrollo en el pensamiento integracionista latinoamericano". 
to pursue the next, and perhaps most challenging step hitherto for the mechanism: the Andean Common Market. Although previous stages were not yet consolidated, at a political level there was the will to advance with the integration. This initiative, however, eluded the possibility of working out a long term strategy that would build on the institutionalization effort of CAN in order to better attain the same goal. ${ }^{41}$

The economic and trade bases of CAN appeared strengthened by the new institutional arrangement. However, these outcomes did not translate into improvements for poverty and inequality. Therefore, social indicators as well as a rules and roles were included as part of the objectives of the mechanism in the Quirama Summit (2003). The creation of the Andean Council of Social Development Ministers and the approval of the Integrated Plan of Social Development show the importance given to this dimension.

Efforts towards an institutionalization of CAN during this period can be regarded as bringing order to an otherwise confusing arrangement. The creation of the Andean Integration System, which implied an administrative and governing structure analogous to that of a state, ${ }^{42}$ is a bet on that direction. That is, member states sought to put things in what they regarded as their right place to facilitate decision-making and the attainment of the mechanism's goals.

Return to individualistic integration: early 2000s - late 2000s

While the aforementioned developments may have seemed optimistic for the mechanism, by the mid 2000s, member states returned to individualistic worldviews. Despite the efforts carried out by CAN in the last 1990s, the results did not meet expectations. Open regionalism did not seem to deliver on the promise of a broader and deeper integration that can move beyond economic and trade concerns, accommodating the interests of member states in multiple dimensions, particularly the social one.

41. Ernani Contipelli, "La Comunidad Andina de Naciones y la evolución del proceso de integración socioeconómico en Latinoamérica", Revista Estudios de Deusto 64, n. ${ }^{\circ} 1$ (2016): 261-80.

42. Ibíd. 
Not only were social indicators not improved, during what is called Latin America's lost decade, they worsened. Barriers to trade were eliminated and austerity measures implemented. In this sense, at the level of policy, it was as if open regionalism's neoliberalism trumped its neo-structuralism. However, even as neoliberal ideas took root, they did not seem to be able to achieve the expected results. Cross-border trade among member states showed some improvement, if any during this period. ${ }^{43}$ Because of this, there was a growing perception that CAN was undergoing a crisis. ${ }^{44}$

Moreover, inside the mechanism, despite the efforts to institutionalize CAN in the previous stage, the mechanism remained tied to intergovernmentalism. Open regionalism, for CAN, proved to be light regionalism. ${ }^{45}$ That is, it was never granted any autonomy or binding decision-making powers. Member states unrelenting adherence to their sovereignty and unwillingness to cede any of it to the common organisms, their unwavering support for consensual decision making instead of a simple majority and their strict opposition to the emergence of an integration law of imperative nature hindered the possibility of CAN becoming anything more than an intergovernmental initiative. ${ }^{46}$ In other words, CAN could not reach supranational level.

Amid this situation, nonetheless, CAN seemed to have accomplished one of its goals when bigger external markets, with high consumption capacity, showed a keen interest in incrementing the trade of goods and services among one another. The United States as well as the European Union expressed their intention to negotiate trade agreements with it. This put the cohesion of the mechanism to the test.

Indeed, perhaps the most salient illustration is of individualistic turn is the hub and spoke strategy implemented by some member states. By 2006, Peru and Colombia established the commitment to sign free trade agreements with the United States. This move is a clear sign of putting self-interest above common-interest. What is more, by definition, these decisions were detrimental to the mechanism as it posed a direct challenge to the consolidation of the customs union.

43. Ibíd.

44. Sanahuja, "Del regionalismo abierto al regionalismo post-liberal".

45. Ibíd.

46. Ibíd. 
This scenario had an additional impact on the mechanism, the loss of a state member. In light of these events, Venezuela announced its departure from the mechanism. Venezuela, under the Chavez administration showed mostly an egalitarian rationality when it comes to regional integration (the objective and principles by which its integration initiative, ALBA, suggest as much) ${ }^{47}$ It seems logical, therefore that this country would regard individualist efforts and threatening the solidarity and equality of CAN.

Therefore, this period is characterized by the primacy of country over region. Member states have mostly and in different ways acted in order to pursue their self-interest. Integration seemed to have been a lose commitment or a temporary arrangement that is subject to constant to individual revision. The events during these years suggest that CAN was supported when it showed some results and it was rejected when it did not. When it was deemed useful in that endeavor, they have resorted to it but they have eschewed it when going about it alone was more effective.

\section{Towards an egalitarian integration? early 2000s - late 2000s}

As was mentioned above, worldviews compete constantly with one another seeking to gain adherents and guarantee, thereby, their survival. This was particularly apparent within CAN from the early 2000s until the late 2000s. During this period, there were considerable efforts to influence the mechanism towards a more egalitarian rationality.

Member states such as Bolivia, Ecuador, and no one more so than Venezuela pushed for the generation of institutions that moved the mechanism towards egalitarianism. The turn to the left explains this situation. By 2007, only a handful of countries in Latin America did not self-identified as leaning to the left or center-left of the political spectrum. ${ }^{48}$ Among those countries were Bolivia, Ecuador, and Venezuela, led by presidents Morales, Correa and Chávez, whose positions and policies resonated so much with the left that were framed within the so-called 21 st century socialism, to different extents, by the presidents and their followers themselves.

47. Garcés, "Latin America at the crossroads".

48. Jorge Castañeda, "Latin America's Left Turn", Foreign Affairs 85, n. ${ }^{\circ} 3$ (2006): 28-43; Matthew Cleary, "Explaining the Left's Resurgence", Journal of Democracy 17, n. 4 (2006): 35-49; Nikolas Kozloff, Revolution! South America and the rise of the new left (New York: Palgrave Macmillan, 2008). 
Both domestically and internationally, these countries implemented initiatives that reflected a move towards egalitarianism. Ideas about sovereignty and the defense of the same weight of all votes within international organizations are but illustrations of the challenge they sought to pose for the status quo. Indeed, attacks on the hierarchical structures and individualistic arrangements dominating the international system were constant. Regarding the former, these countries pushed for fundamental changes on organizations such as the Security Council of the United Nations, at best, or more representation of other than traditional states, at worse. Apropos of the latter, these countries led a charge against arguably the greatest individualistic initiative in the region: The Free Trade Area of the Americas (FTAA or ALCA by its acronym in Spanish), an effort that had been in the works for more than a decade. In this sense, the intention of Venezuela of establishing an egalitarian regional integration moved it to lead an alternative, namely the Bolivarian Alliance for the Peoples of Our America (or its acronym in Spanish: ALBA).

Eventually, the lack of advancement in the road towards solidarity and equity in CAN took a rather meaningful toll. The disagreement with the position held by CAN, in particular the free trade agreements signed by Colombia and Peru with the United States ${ }^{49}$ led to Venezuela's decision to opt out of the mechanism and the threat by Bolivia of following suit. Efforts were, therefore, dedicated to furthering ALBA. The result was the inclusion of the Peoples' Trade Treaty, which was so significant so as to be added to the name of the mechanism (ALBA-TCP, by if acronym in Spanish). This initiative had the purpose of uniting member states under the banner of equality and solidarity in order to face individual and common challenges.

The efforts during this period to influence CAN with egalitarian ideas, or at least not to allow it to fall to other worldviews, in particular the individualistic one, were unsuccessful. They were to some extent useful, nonetheless, as they highlighted important aspects that would need to be addressed in order to guarantee the survival of the mechanism

49. Sanahuja, "Del regionalismo abierto al regionalismo post-liberal". 


\section{Reappearance of an individualistic integration: early 2010s - mid 2010s}

During the second decade of the new millennium, CAN faced important new challenges. Politically, at the highest level, the momentum gained in previous years seemed effectively lost. While there were ten meetings of the Andean Presidential Council between 2000 and 2007, there were none between 2008 and 2010, and only five from 2011 and 2019, two in 2011 and three in 2019, none in the seven years in between.

Furthermore, member states during this period have expressed concerns regarding the mechanism and the possibility of opting out of it. Following the Venezuela's decision, Bolivia expressed similar concerns in 2006 and announced the possibility of leaving CAN as it would make little sense if members sign free trade agreements with third countries. Additionally, in 2012, on the face of an increasing belief and concern that Bolivia's role within CAN would be jeopardized by its acceptance of the invitation made to it to become a full member of MERCOSUR, Bolivia had to reassure CAN member states that this would not be the case and that it would continue to participate in the Andean initiative and endeavor the advancement of the Andean Community.

Ecuador has periodically manifested its skepticism of the benefits of CAN when its interests have been threatened. In this sense, in 2009 it announced that it would reconsider its membership in light of the mechanism's possibility of sanctioning the country on the bases of an analysis of the application of the balance of payments safeguard implemented by Ecuador on 627 products. In 2011, a similar announcement was made given the difficulties that Ecuadorian transport was experiencing to cross borders to Colombia and Peru. This position led to the reactivation of the Andean Presidential Council, which had not met in the two years prior to the event, and the commitment to modernize the mechanism in order to overcome its increasingly evident shortcomings.

Most recently, in 2015 and again in 2016, Ecuador insisted on its concern with the mechanism and the possibility of leaving it. In 2015, the reason was CAN's position against the country's implementation of exchange rate safeguards against neighboring Colombia and Peru, $21 \%$ and $7 \%$, respectively. In 2016, Ecuador expressed its worry about its disadvantageous position by being part of a free trade zone with countries that can 
appreciate or depreciate their currencies. The lack of tools to address this situation, as dollarization entails not possibility to implement monetary policy and the free trade zone hinders the possibility to resort to trade policy, was raised a major concern in light of an increasing deficit in the trade balance with these member states.

Hence, during this period, some member states seem to have adhered mostly to a rather individualistic worldview, as they have prioritized their self-interest above that of the mechanism. They seem to have regarded CAN as nothing more than a means to reach individual advantages. Their membership seems to be dependent on the extent to which they are able to reach it. Should CAN pose a hindrance to the pursuit of their goals, these members have shown their willingness to reconsider their participation. In this sense, this period has also shown the use of state membership as a bargaining chip in order for them to obtain their objectives.

\section{Conclusion}

CAN, as a regional integration mechanism, is a means to attain some ends. Throughout its 50 years of existence, it has showed mixed record in terms of its results. Because of this, at different moments, it has been declared in crisis, with its very survival on the line. Different member states, on the face of diverse challenges, have expressed their skepticism regarding the usefulness of the mechanism, at best, or have threatened to leave and have opted out of it, at worst. As such, CAN itself could be regarded as a problem in need of solution. Despite these shortcomings, CAN has proven to be resilient and successful in securing its survival. It has been argued that this ca be explained by its ability to adapt to different situations and scenarios.

In order to address the problem that CAN has posed and its adaptation in order to generate useful solutions, this article has built on the relevant literature regarding Latin American integration as a wicked problem ${ }^{50}$ as well as on the literature advancing grid-group cultural theory as a framework useful to analyze such problems. GG cultural theory advances a functionalist alternative to the scrutiny of socio cultural viability, focusing on

50. Garcés, "Latin America at the crossroads". 
the social construction of the perceptions from which the world becomes intelligible. The combination of the grid and group dimensions leads to the generation of four mutually exclusive and jointly exhaustive ways of life: hierarchy, individualism, egalitarianism and fatalism. These worldviews or rationalities influence interpretations of reality, the construction of its meanings. Of particular interest has been the interpretations given to themes relevant to regional integration, besides human agency and organization: conflict and cooperation.

Applied the historical overview of CAN, has showed an oscillation between hierarchy and individualism. From its conception (1969) until the late 1980s, the mechanism emphasized the pursuit of individual self-interest via the establishment of a free market to better compete in an individualistic world. From late 1980s until the early 2000s, there was a consistent push for more institutionalization within CAN, putting things in their place and assigning functional competences to different instances. From the early 2000s until the late 2010s, there seems to have been a return to individualistic worldview, although different that the original one, leading member states to prioritize their self-interest, reaching out to third parties individually when convenient. Overlapping with this period, from early 2000s until the early 2010s, CAN experienced some pressures to turn towards egalitarianism which ultimately proved unsuccessful and led to the departure of Venezuela. Finally, from the early 2010s until the mid 2010s there seems to be a reappearance of individualistic rationalities, perhaps best exemplified by Ecuador's multiple threats to leave the mechanism when it regarded it as a hindrance to its interests.

Consequently, the presence of hierarchical and individualistic worldviews within CAN have posed important challenges for the integration. CAN has proven resilient and skillful in adapting to these rationalities. Moreover, it has also proven to be able to fend off egalitarianism when under pressure from it. Looking forward, on the face of a current return of liberal ideas on the region with initiatives such as PROSUR, the strengthening of the Pacific Alliance, and the rejection of more egalitarian mechanisms such as UNASUR, ${ }^{51}$ CAN is very likely to once again overcome this period and, learning from its past experience, perhaps even take advantage of it.

51. Ibíd. 


\section{References}

Bell, Wendy. An Anthropological View of How Organizations Think. Melbourne: Monash University Faculty of Business \& Economics, 1997.

Briceño Ruiz, José. "Autonomía y desarrollo en el pensamiento integracionista latinoamericano". In Integración Latinoamericana y Caribeña: Política y Economía, edited by José Briceño, Andrés Rivarola, and Ángel Casas, 27-54. Madrid: Fondo de Cultura Económica, 2012.

"Regionalismo estratégico e interregionalismo en las relaciones externas del MERCOSUR”. Revista Aportes para la Integración Latinoamericana 12, n. ${ }^{\circ} 15$ (2006): 30-45.

y Raquel Álvarez. "Modelos de Desarrollo y estrategias de integración en América Latina: una revisión crítica". Cuadernos sobre Relaciones Internacionales, Regionalismo y Desarrollo 1, n. 1 (2006): 63-87.

Casteñeda, Jorge. "Latin America's Left Turn”. Foreign Affairs 85, n. 3 (2006): 28-43. Cleary, Matthew: "Explaining the Left's Resurgence". Journal of Democracy 17, n. 4 (2006): 35-49.

Contipelli, Ernani. "La Comunidad Andina de Naciones y la evolución del proceso de integración socioeconómico en Latinoamérica”. Revista Estudios de Deusto 64, n. ${ }^{\circ} 1$ (2016): 261-80. 〈https://bit.ly/2HMGQNF〉.

De Lombaerde, Philippe. "El Nuevo Regionalismo en América Latina”. UNU-CRIS Ocasional Papers O-2005/3, (2005): 1-24.

Douglas, Mary. In the Acting Voice. Boston: Routledge \& Kegan Paul, 1982.

Garcés, Pablo. "Latin America at the crossroads: cultural theory to address the wicked problem of regional integration with clumsy solutions". Revista de Relaciones Internacionales, Estrategia y Seguridad 14, n. ${ }^{\circ} 2$ (2019). doi:10.18359/ries.2889 "Latin American integration as a wicked problem: the case for a plural approach". Revista de Relaciones Internacionales, Estrategia y Seguridad 13, n. 1 (2018): 93-117. doi:10.18359/ries.2890

Hood, Christopher. The Art of the State: Culture, Rhetoric and Public Management. Oxford: Oxford University Press, 1998.

Kozloff, Nikolas. Revolution! South America and the rise of the new left. New York: Palgrave Macmillan, 2008.

Lockhart, Charles. "The Social Construction of Cooperation: Egalitarian, Hierarchical, and Individualistic Faces of Altruism". In Culture and Social Theory / Aaron Wildawsky, edited by S-K. Chai and Brendon Swedlow, 113-31. London: Transaction Publishers, 1998.

Riggirozzi, Pía. "Re-territorializando consensos: Hacia un regionalismo post-hegemónico en América Latina”. In América Latina y el Caribe: Nuevos actores, nuevos temas, nuevos desafíos, edited by Andrés Serbin, Laneydi Martínez, Haroldo Ramanzini, 129-51. Buenos Aires: Coordinadora Regional de Investigaciones Económicas y Sociales, 2012. 
Rittel, Horst and Melvin Weber, "Dilemmas in a general theory of planning". Policy Sciences 4, n. 2 (1973): 155-69. doi:10.1007/BF01405730

Sanahuja, Antonio. "Del regionalismo abierto al regionalismo post-liberal: crisis y cambio en la integración latinoamericana”. In Anuario de la integración regional de América Latina y El Caribe, edited by Laneydi Martínez, Lázaro Peña and Mariana Vázquez, 11-54. Buenos Aires: Coordinadora Regional de Investigaciones Económicas y Sociales, 2008.

- "Regionalismo Postliberal y Multilateralismo en Sudamérica: el caso de UNASUR" en América Latina y el Caribe: Nuevos actores, nuevos temas, nuevos desafíos. edited by Andrés Serbin, Laneydi Martínez, Haroldo Ramanzini, 19-72. Buenos Aires: Coordinadora Regional de Investigaciones Económicas y Sociales, 2012.

Thompson, Michael. "Cultural Theory, Climate Change and Clumsiness". Economic and Political Weekly 38, n. ${ }^{\circ} 48$ (2003): 5107-12.

and Richard Ellis. "Introduction: Political Cultures", in Culture and Social Theory / Aaron Wildavsky, edited by Chai, Sun-Ki and Brendon Swedlow, 1-13. London: Transaction Publishers, 1998.

Thompson, Michael, Richard Ellis and Aaron Wildavsky. Cultural Theory. Oxford: Westview Press, 1990. 